\title{
OPTIMALISASI PENGABDIAN MASYARAKAT PADA SEKOLAH PAUD BINAAN
}

\author{
( Made Ardika Yasa1) \\ 1)Program Studi PG-PAUD, Jurusan Dharma Acarya, STAHN Gde Pudja Mataram, Mataram, Indonesia \\ Corresponding author : I Made Ardika Yasa \\ E-mail :kpjm.ardika@gmail.com
}

Diterima 24 Maret 2021, Direvisi 01 April 2021, Disetujui 02 April 2021

\begin{abstract}
ABSTRAK
Penulisan hasil Pengabdian masyarakat ini bertujuan untuk menggambarkan peningkatan optimalisasi pengabdian masyarakat pada Sekolah PAUD Binaan STAHN Gde Pudja Mataram sehinggaproses pembelajaran di lembaga Pendidikan Anak Usia Dini yang saat ini tidak hanya terbatas teori pada pertemuan atau tatap muka di kelas saja, tapi terus berkembang dengan prangkat dan metode pembelajaran yang menggunakan media peraga. Proses pelaksanaan kegiatan dilakukan dengan mengadakan perencanaan, pelaksanaan dan evaluasi. Adapun dari pelaksanaan kegiatan pengabdian ini merupakan wujud aplikasi dalam melaksanakan salah satu Tri Dharma Perguruan Tinggi pada aspek Pengabdian Masyarakat, sasaran dari kegiatan ini ialah Sekolah PAUD binaan Program Studi PGPAUD jurusan Dharma Acarya Sekolah Tinggi agama Hindu Negeri Gde Pudja Mataram dimana seperti yang telah kita ketahui bahwa Sekolah PAUD atau Taman Kanak-kanak merupakan salah satu bentuk lembaga pendidikan anak usia dini yang dalam proses pembelajarannya menekankan pada prinsip bermain sambil belajar dan belajar seraya bermain. Optimalisasi pembinaan juga bertujuan untuk mengembangkan pendidikan karakter khususnya yang berlandaskan ajaran agama Hindu sejak dini bagi anak-anak. Oleh karenanya kegiatan pengabdian ini begitu penting, sehingga melalui penulisan laporan ini dapat memberikan gambaran manfaat kegiatan yang dilakukan dan memberikan penguatan wawasan mengenai pentingnya pendidikan dan optimalisasi binaan terhadap pendidikan anak usia dini khususnya dalam pengembangan karakter.
\end{abstract}

Kata kunci: optimalisasi; pengabdian masyarakat; paud binaan.

\begin{abstract}
This community service aims to improve the optimization of community service at the STAHN Gde Pudja Mataram PAUD School, so that the learning process in Early Childhood Education, which is currently not limited to theory only at meetings or face-to-face class meetings. , but continues to develop with learning methods and tools that use visual media. As for this service activity as a form of application in implementing one of the Tri Dharma Perguruan Tinggi in the aspect of Community Service, the target of this activity is the PAUD Schools assisted by the PG-PAUD Study Program majoring in Dharma Acarya, the State College of Hindu Religion Gde Pudja Mataram where as already we know that PAUD School or Kindergarten is a form of early childhood education institution which in the learning process emphasizes the principle of playing while learning and learning while playing The writing of the results of community service aims to describe the improvement of optimization of community service at the PAUD School Assisted by STAHN Gde Pudja Mataram so that the learning process in early childhood education institutions that are currently not only limited to meetings or face-to-face in the classroom but continues to develop with a prank at and learning methods that use media props. The process of carrying out activities is carried out by conducting planning, implementation and evaluation. As for the performance of this holy activity is a form of application in carrying out one of the Tri Dharma Of Higher Education in the aspect of Community Service, the target of this activity is paud school assisted by PGPAUD Study Program majoring in Dharma Acarya State Hindu High School Gde Pudja Mataram. In contrast, we already know that PAUD School or Kindergarten is one form of an early childhood education institution that in the learning process emphasizes the principle of playing while learning and learning while playing. Optimization of coaching also aims to develop character education, primarily based on Hindu teachings early on for children. Therefore, this holy activity is so essential that the writing of this report can provide an overview of the benefits of activities carried out and provide reinforcement of insights on the importance of education and optimization of the development of early childhood education, especially in character development.
\end{abstract}

Keywords: optimization; community dedication; paud assisted. 


\section{PENDAHULUAN}

Pendidikan anak usia dini merupakan pendidikan yang sasaran utamanya ialah anak usia di bawah tujuh tahun, yang seperti kita ketahui kondisi kejiwaan pada masa tersebut masih labil sehingga sangat mudah berubahubah.Didalam satu kelas masing-masing anak memiliki karakter yang berbeda atau beraneka ragam misal ada yang cenderung aktif, agresif, pasif dan bahkan ada yang pemaluhal itu dipengaruhi oleh faktor eksternal dan faktor internal, adapun faktor internal yang mempengaruhi ialah pola asuh orang tua dan keadaan situasi dan kondisi kehidupan didalam keluarga anak sebab keharmonisan dan curahan kasihsayang orang tua sangat besar pengaruhnya dalam pmbentukan karakter pribadi anak. Sedangkan faktor eksternal yang mempengaruhi sifat dan karakter anak ialah lingkungan dan pergaulan anak karena anak usia dini merupakan masa menduplikasi dimana pada masa ini anak tersebut cenderung meniru hal-hal yang dianggap menarik perhatiannya terlepas dari konteks baik atau buruk hal yang mereka tiru, pada dasarnya perbedaan karakter itu juga akan mempengaruhi daya serap ataupun respon anak terhadap stimulus dalam setiap proses pembelajaran oleh karena itu pada masa inilah merupakan saat yang paling tepat untuk menanamkan prilaku positif sesuai dengan nilai-nilai ajaran agama yang dianut (Khaironi, 2017).

Pengabdian masyarakat mandiri program studi PG-PAUD pada sekolah PAUD binaan, dengan tema" Optimalisasi Pengabdian Masyarakat Pada Sekolah PAUD Binaan" sebagai salah satu wujud aplikasi dalam melaksanakan salah satu Tri Dharma Perguruan Tinggi pada aspek Pengabdian Masyarakat, sasaran dari kegiatan ini ialah Sekolah PAUD binaan Program Studi PGPAUD jurusan Dharma Acarya Sekolah Tinggi agama Hindu Negeri Gde Pudja Mataram dimana seperti yang telah kita ketahui bahwa Sekolah PAUD atau Taman Kanak-kanak merupakan salah satu bentuk lembaga pendidikan anak usia dini yang dalam proses pembelajarannya menekankan pada prinsip bermain sambil belajar dan belajar seraya bermain. Sebab tidak dapat dipungkiri bahwa bermain merupakan salah satu unsur terpenting dalam kehidupan setiap anak dan merupakan media terbaik dalam mengembangkan bakat serta kemampuan anak secara optimal(Kunandar, 2008).

Penggunaan metode bermain
disesuaikan dengan kebutuhan dan
perkembangan usia anak. Permainan yang
digunakan anak sekolah PAUD atau Taman

Kanak-kanak adalah permainan yang merangsang kreativitas sehingga menimbulkan rasa yang menyenangkan tanpa ada unsur paksaan dan bersifat sederhana(Mursid, 2015).

Demikian juga dengan kegiatan olahraga untuk anak usia dini hendaknya disesuaikan dengan perkembangan usia dan keperluannya. Setiap kegiatan proses pembelajaran merupakan salah satu upaya transfer pengetahuan sebab, transfer pengetahuan adalah sebuah konsep untuk menginformasikan dalam proses pembelajaran di pendidikan anak usia dini baik di pendidikan formal maupun pendidikan informal (Arta wiguna, 2020). Pembinaan dalam rangka merangsang pengembangan saraf motorik siswa-siswi di sekolah PAUD Dewi Ratih merupakan salah satu kegiatan yang dapat mengembangkan aspek motorik secara optimal dan secara tidak langsung akan dapat merangsang perkembangan otak anak dengan menggunakan media Alat Permainan Edukatif dan tayangan video edukatif dengan LCD Proyektor yang dimana sebelumnya siswa PAUD Dewi Ratih dalam kegiatan proses pembelajaran hanya menggunakan metode ceramah saja.

Permasalahan dalam melaksanakan proses pengelolaan Sekolah PAUD sangatlah komplek sehingga butuh pembinaan secara intensif, agar dapat memberikan solusi dalam mengatasi permasalahan tersebut adapun permasalahan yang dihadapi ialah 1 . Kurangnya sarana dan prasarana pendudkung dalam proses pembelajaran seperti buku ajar/buku bacaan anak usia dini, perangkat computer, dan alat peraga. 2. Biaya operasional merupakan Uang sumbangan masyarakat yang nominalnya sangat kecil maka hanya untuk dapat mencukupi bahan belajar murid namun untuk honor para tenaga pendidik belum dapat terpenuhi, 3. Kurangnya perhatian orang tua siswa dalam berpartisipasi memberikan edukasi dilingkungan keluarga karena beranggapan pendidikan anaknya hanyalah cukup di serahkan sepenuhnya pada tenanga pendidik di PAUD Dewi Ratih sehingga orang tua siswa setelah mengantar anaknya langsung pergi meninggalkan anaknya yang kesanya PAUD hanyalah seperti tempat penitipan anak bagi orang tua siswa yang memiliki kesibukan padat.Fenomena ini hendaknya menjadi tantangan bagi bangsa Indonesia, sebab pendidikan itu seharusnya mampu menjadi wahana agar dapat mendukung proses pengembangan dan rekonstruksi watak serta peradaban bangsa(Hadisi, 2015). Dengan demikian maka perguruan tinggi akan terus tertantang untuk dapat berinovasi dalam melaksanakan perannya untuk menjalankan 
tridarma perguruan tinggi, salah satunya ialah dengan mulai merespon perkembangan teknologi untuk meningkatkan perannya dalam melaksanakan pelayanan publik dalam bentuk pengabdian mayarakat sehingga dalam melaksanakan salah satu tugasnya yaitu pengabdian masyarakat dapat secara efektif dan efisien sehingga menghasilkan pencapaian yang optimal sehingga dapat memberikan solusi atas permasalahan yang dialami oleh PAUD Binaan yang pada kesempatan ini berlokasi di PAUD dewi Ratih sehingga ditawarkannya beberapa solusi untuk menghadapi dan menyelesaikan permasalahan tersebut diatas yaitu 1. Memberikan pemahaman kepada tenaga pendidik PAUD Dewi Ratih bahwa pelaksanaan proses pembelajaran tidak hanya dengan metode ceramah saja dan memberikan alternative metode lain untuk kegiatan pembelajaran seperti mengajar dengan alat peraga ataupun alat permainan edukatif. 2. Memberikan arahan dan meningkatkan keterampilan tenaga pendidik PAUD Dewi Ratih terkait tata cara membuat Alat Permainan Edukatif yang murah, mudah, efektif, efisien yang terbuat dari bahan bekas dimana bahan tersebut mudah untuk diperoleh yang dapat ditemukan pada lingkungan sekitar misal seperti botol plastik bekas, kardus, ranting, daun kering dan lain sebagainya. 3. Memberikan contoh dan pemahaman tentang cara membuat proposal yang baik dan benar dan kemana tujuan proposal tersebut di ajukan agar tepat sasaran guna menambah pemasukan dana swadaya masyarakat dalambentuk sumbangan. 4. Memberikan sumbangan dalam bentuk beberapa jenis alat peraga atau alat permainan edukatif, dan buku bacaan anak untuk perpustakaan PAUD Dei Ratih .

\section{METODE}

Tri Dharma Peguruan Tinggi adalah suatu kewajiban yang harus dilaksanakan oleh institusi Pendidikan Tinggi, salah satunya ialah kegiatan pengabdian kepada masyarakat (Gunada \& Yoga Pramana, 2021). Kegiatan Pengabdian kepada masyarakat ini dilaksanakan secara mandiri dalam rangka melaksanakan salah satu kegiatan aktualisasi nilai-nilai dasar Pegawai Negeri Sipil pada masa Habituasi Calon Pegawai Negeri Sipil dan sekaligus melaksanakan salah satu tugas tri dharma perguruan tinggi dibidang pengabdian masyarakat.

Pengabdian masyarakat ini memilih lokasi di PAUD Dewi Ratih dengan dasar pertimbangan bahwa PAUD Dewi Ratih merupakan salah satu PAUD Binaan STAHN Gde Pudja Mataram yang telah melakukan
MOU dengan Program Studi PG-PAUD STAHN Gde Pudja Mataram dan memiliki sarana prasarana yang cukup memadai namun kurang tersentuh didalam pelaksanaan kegiatan pengabdian. Setiap kegiatan tentunya memiliki jadwal sebagai acuan dalam pelaksanaan kegiatan begitu juga dengan pengabdian masyarakat mandiri di PAUD Dewi Ratih ini memiliki jadwal seperti yang tertera pada Tabel 1 dibawah ini:

Tabel.1. Jadwal Pelaksanaan Kegiatan

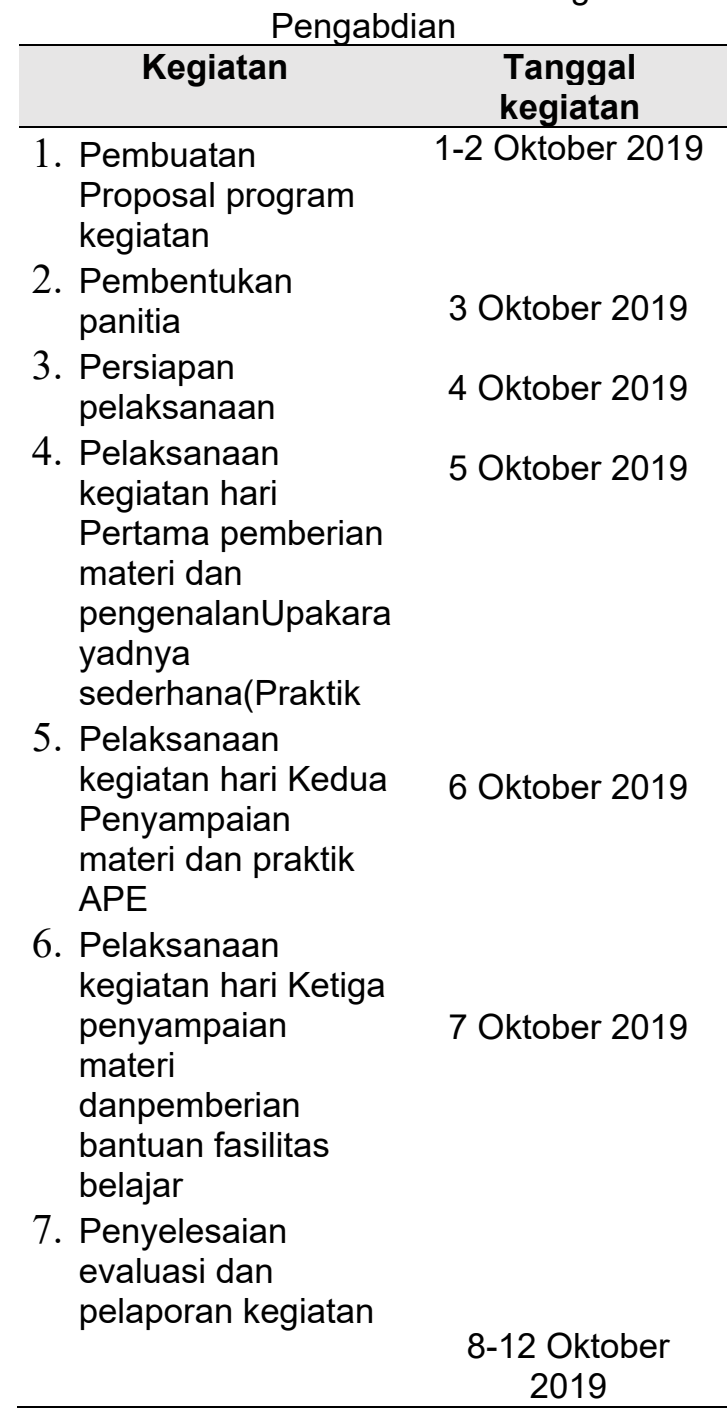

Kegiatan Pengabdian masyarakat mandiri di PAUD Dewi Ratih ini melalui beberapa tahapan yaitu;

\section{Tahap Pra Kegiatan}

Sebelum melaksanakan kegiatan pengabdian terlebih dahulu pelaksana pengabdian melakukan diskusi, sharing dan menggali informasi kepada Ketua Program Studi PG PAUD STAHN Gde Pudja Mataram agar mendapatkan masukan terkait lokasi pelaksanaan kegiatan pengabdian, setelah mendapat masukan maka disusun TOR dan Proposal Kegiatan dan mengajukannya ke 
lembaga STAHN Gde Pudja Mataram untuk mendapat Surat Keputusan Pelaksanaan Kegiatan dan Surat Tugas.

Kegiatan ini dilaksanakan bertempat di Jalan Biaq Ganggas No.40 Karang Tangkeban Cakra Selatan diikuti sebanyak 45 orang peserta. Adapun peserta terdiri dari Siswa, orang tua siswa, Guru PAUD Dewi Ratih, Mahasiswa dan Dosen Stahn Gde Pudja Masyarakat. Pada tahap ini rencana dan program persiapan perencanaan pengabdian yang meliputi pembentukan panitia melalui rapat lembaga, usulan pengajuan judul, melakukan pengumpulan, pengolahan, klarifikasi dan penyajian data lokasi pengabdian masyarakat, penyusunan Surat Keputusan (SK), dan penyusunan RAB;

\section{Tahap Kegiatan}

Merupakan Tahap kedua yaitu tahap pelaksanaan rencana dan kegiatan dimana pada tahapan ini pelaksana pengabdian menentukan susunan acara program kegiatan pengabdian masyarakat, rencana persiapan sarana dan prasarana pendukung kegiatan, merumuskan tindak lanjut realisasi dan pelaksana rencana kegiatan;

Pada awal kegiatan siswa PAUD Dewi Ratih diberikan semacam pretest secara lisan untuk mengukur sejauh mana keterampilan, kemampuan dan pengetahuan dasar siswa sebelum siswa PAUD Dewi Ratih mendapatkan materi dalam bentuk Praktik, Ceramah, dan diskusi berdasarkan sesi tanya jawab dari para peserta (teori dan praktik). Dan pada akhir kegiatan Siswa PAUD Dewi Ratih diberikan postes untuk mengukur sejauh mana ketercapaian kegiatan proses pembelajaran yang disampaikan oleh pelaksana kegiatan Pengabdian masyarakat mandiri. Dalam pelaksanaan kegiatan penyampaian materi menggunakan alat praga yang disiapkan oleh pelaksana kegiatan dan dibantu secara partisipatif oleh orang tua Siswa PAUD Dewi Ratih.

Karena sasaran utama dari kegiatan pengabdian ini adalah anak usia dini maka untuk meningkatkan semangat, motivasi, antusias siswa paud mengikuti proses pembelajaran maka didalam pelaksanaan kegiatan proses pembelajaran pada lokasi pengabdian, pelaksana kegiatan dominan menggunakan metode bermain dalam proses pembelajaran. Metode bermain adalah kegiatan yang anak-anak lakukan sepanjang hari karena bagi anak bermain adalah hidup dan hidup adalah permainan (Mayesty,1990:196-197).

Selain itu agar anak merasa senang dan gembira serta nyaman dalam mengikuti proses pembelajaran maka didalam kegiatan pembelajaran Pelaksana Kegiatan juga menggunakan metode bernyanyi dimana bernyanyi merupakan salah satu kegiatan yang sangat digemari oleh anak-anak. Hampir setiap anak sangat menikmati lagu-lagu atau nyanyian yang didengarkan, lebih-lebih jika nyanyian tersebut dibawakan oleh anak-anak seusianya dan diikuti dengan gerak-gerakan tubuh yang sederhana(Mursid, 2015).

\section{Tahap Monitoring dan Evaluasi}

Pada tahapan ke tiga ini panitia pelaksana melaksanakan proses monitoring ke PAUD Dewi Ratih untuk observasi dan mewawancarai tenaga pendidik, orang tua siswa dan siswa PAUD Dewi Ratih agar mendapatkan informasi sejauh mana keberhasilan kegiatan pengabdian mandiri ini baik dilihat dari perubahan segi sikap, keterampilan dan pengetahuan anak setelah itu seluruh data dan informasi tersebut di reduksi, dan dianalisis setelah itu dituangkan pada pelaporan pelaksana kegiatan dimana pada tahapan ini laporan kegiatan disampaikan kepada Ketua Panitia Pengabdian masyarakat setelah berakhirnya kegiatan pengabdian untuk dievaluasi dan setelah itu laporan kegiatan yang telah dibuat dan dievaluasi di sahkan serta disampaikan kepada Ketua STAHN Gde Pudja Mataram.

\section{HASIL DAN PEMBAHASAN}

Berdasarkan hasil analisa terkait kegiatan Pengabdian Masyarakat secara mandiri yang dilakukan di PAUD Dewi Ratih maka dapat dijelaskan sebagai berikut :

Bahwa setiap Kegiatan tentunya harus memiliki jadwal rencana kegiatan sebelum kegiatan tersebut diselenggarakan, agar terlaksana dengan sistematis dan berjalan lancar, dengan demikian maka kegiatan inipun dilaksanakan sesuai jadwal rencana kegiatan pengabdian kepada masyarakat yaitu pada awal bulan Oktober tahun 2019 sesuai dengan jadwal pelaksanaan kegiatan pengabdian masyarakat yang telah dilaksanakan dan tertera pada tabel 1 .

Sebelum kegiatan pengabdian masyarakat ini terselenggara maka dipersiapkan terlebih dahulu administrasi kegiatan baik dalam bentuk SOP,TOR ataupun SK Pelaksanaan Kegiatan, setelah administrasi pelaksaanan selesai maka Kegiatan Pengabdian Mayarakat ini diselenggarakan hari Sabtu tanggal 5 Oktober 2019 sampai dengan tanggal 7 Oktober 2019, bertempat di Pendidikan Anak Usia Dini (PAUD) Dewi Ratih yang berkedudukan di Jalan Biaq Ganggas No.40 Karang Tangkeban Cakra Selatan diikuti 
sebanyak 45 orang peserta yang telah terlaksana dengan baik.

\section{Pemberian materi dan pengenalan Upakara yadnya sederhana}

Seperti yang kita ketahui upakara merupakan salah satu korban suci untuk persembahan kepada Tuhan yang dilakukan oleh umat Hindu sebagai wujud syukur atas berkah dan anugerah Tuhan, adapun jenis sarana upakara atau sesaji yang digunakan sebagai persembahan yang dibuat oleh umat Hindu memiliki tiga tingkatan yaitu Utama, Madya dan Nista sebab sarana upakara tersebut merupakan korban suci yang tulus dan ikhlas jadi harus disesuaikan dengan kemampuan atau tingkatan maupun kemampuan ekonomi yang melaksanakan persembahan tersebut sehingga sering dijumpai sarana upakara yang beraneka ragam sebab mengikuti budaya yang berkembang pada daerah masing-masing(Jayanti et al., 2017).

Didalam kegiatan pengabdian masyarakat mandiri ini pelaksana kegiatan memberikan materi dan praktik pengenalan sarana upakara yadnya yang bentuknya sederhana atau tingkatan madya kepada siswa PAUD Dewi Ratih sebab walaupun guru dan orang tua siswa ikut berpartisipasi membantu namun tetaplah sasaran utamanya Siswa PAUD Dewi Ratih yang masih berusia dibawah 7 tahun jadi disesuaikan dengan kemampuan dan daya tangkap anak tersebut sehingga kegiatan ini secara maksimal akan dapat menstimulus kemampuan sensorik dan motorik anak.

Pada sesi kegiatan ini pelaksana kegiatan memberikan materi tentang pengenalan sarana upakara sederhana berupa Canang sari seperti pada Gambar 1.yang merupakan salah satu bentuk upakara yang dibuat berbahan dasar dari daun kelapa muda yang sering disebut dengan janur yang dihiasi oleh beberapa komponen bahan lain berupa bunga, daun pandan yang di suir, beras yang direndam air, dan daun sirih yang dimana menurut kepercayaan umat Hindu khususnya yang berdomisili di Bali dan Lombok.Canang tersebutseperti pada Gambar 2. merupakan salah satu sarana upakara yang sederhana untuk melakukan persembahyangan, tanpa dipungkiri Metanding dan menghaturkan Canang sarimerupakan salah satu aktivitas rutin umat Hindu yang tinggal di Bali maupun Lombok terutama bagi kaum wanita sehingga tanpa disadari telah menjadi sebuah budaya yang dapat memberikan nilai-nilai pendidikan estetika dan pemahaman bahwa betapa pentingnya budaya lokal yang memiliki makna filosofi yang mendalam tentang falsafah kehidupan maupun ketuhanan yang dapat meningkatkan sradha dan bhakti kita kepada tuhan, alangkah baiknya jika hal ini tidak hanya umat Hindu saja yang menyadari tetapi seluruh umat manusia untuk menjaga keharmonisan, keselarasan dan keseimbangan lingkungan karena didalam ajaran umat Hindu dikenal dengan Ajaran Tri Hita Karana yang mengajarkan umat Hindu agar dapat selaras dengan lingkungan dan seimbang dalam menjalani hidup baik hubungan secara vertikal maupun horizontal (Hariana, 2017).

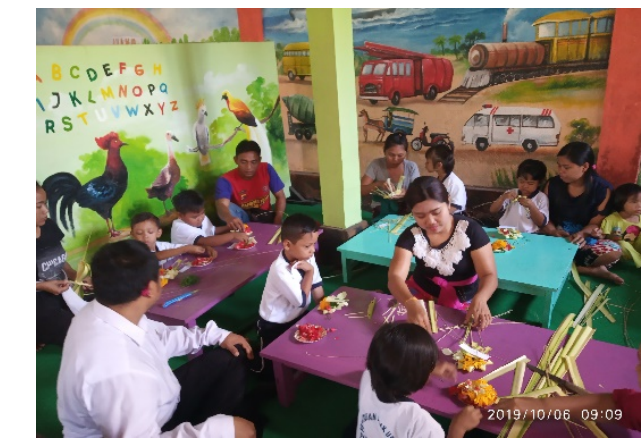

Gambar 1. Pengenalan dan Praktek

Pembuatan Canang sari ( Sumber: I Made Ardika Yasa)

Agama Hindu memiliki tiga kerangka dasar yaitu sering dikenal dengan sebutan tri kerangka dasar agama Hindu yakni tattwa, susila dan upacaradimana dalam pelaksanaan yadnya sebagai wujud sembah sujud puji syukur dan bhakti kepada Ida Sang Hyang Widhi atau Tuhan Yang Maha ESAmaka umat Hindu tidak dapat mengesampingkan ketiga aspek tersebut sebab ketiga aspek tersebut bagaikan dua sisi mata uang yang jika dipisahkan maka tidak memiliki nilai yang berarti, sehingga didalam pelaksanaan upacara yadnya umat Hindu menggunakan beraneka ragamjenis, bentuk, dan rupa sarana dan prasarana upakara tersebut sesuai desa kala patra yang membentuk tradisi, budaya dan tingkatan sosial yang mempengaruhi kemampuan umat untuk memilih salah satu dari tiga tingkatan kelas sarana upakara yadnya yaitu utama, madya dan nista namun sarana upakara tersebut tetaplah terbuat dari bahan dasar bunga, dupa, air, beras, daun, buah dan kwangen, sebab sarana tersebut diyakini oleh umat Hindu merupakan persembahan sebagai wujud bhakti dan syukur atas berkah yang telah dianugerahkan oleh Ida Sang Hyang Widhi Wasa(Studi et al., 2020).

Dengan demikian dapat kita sadari bahwa betapa besarnya manfaat dan betapa dalamnya makna serta filosofi dari Canang saritersebut sehingga hal ini menjadi dasar pertimbangan, pelaksana kegiatan pengabdian 
masyarakat mandiri yang dilaksanakan di PAUD Dewi Ratih memilih Canang sari sebagai materi pengenalan dan praktek sarana upakarayadnya sederhana untuk disampaikan kepada siswa PAUD yang mayoritas anak usia dibawah 7 tahun sehingga secara tidak langsung dapat terpatri nilai-nilai dasar ajaran agama Hindu yang dapat membentuk karakter yang kuat, dan pribadi yang siap dari segi mental untuk dimasa mendatang melanjutkan jenjang pendidikan yang lebih tinggi.

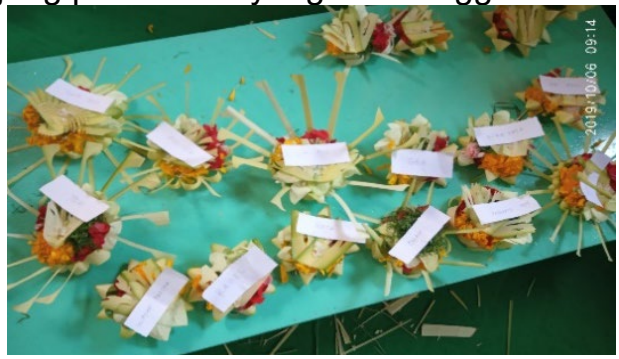

Gambar 2.Hasil karya siswa PAUD Dewi Ratih saatPraktek Pembuatan Canang sari

( Sumber: I Made Ardika Yasa)

\section{Penyampaian materi dan praktik APE}

APE merupakan singkatan dari Alat Peraga Edukatif yang juga dikenal dengan istilah Alat peraga pembelajaran yang merupakan media yang digunakan oleh tenaga pendidik dalam proses kegiatan belajar mengajarsehingga dapat mengantisipasi terjadinya verbalisme pada dirisiswa. Sebab seperti yang diketahui alat peraga mempunyai fungsi utama untuk menurunkan keabstrakan dari konsepserta menghilangkan verbalisme pada diri peserta didik, sehingga peserta didik dapat memaknai dan menganalisis arti yang sebenarnya dari konsep tersebut.Dengan melihat, meraba, dan memanipulasi media peraga sehingga peserta didik memiliki pengalamannyata dalam kehidupan sehari-hari tentang arti dari suatu konsep (Kaltsum, 2017).

Pada sesi ini Pelaksana Kegiatan Pengabdian mandiri memahami bahwa untuk menarik minat dan menggali potensi siswa PAUD yang dimana usia mereka masih dibawah usia 7 tahun tentunya membutuhkan media yang tepat sehingga dapat merangsang daya tarik anak usia dini sehingga siswa tersebut dapat secara partisipatif, merasa nyaman dan bersemangat dalam mengikuti kegiatan proses belajar mengajar dari awal sampai akhir tanpa merasa bosan, maka oleh sebab itu pelaksana kegiatan pengabdian masyarakat secara mandiri di PAUD Dewi Ratih menggunakan beberapa alat peraga edukatif dan memberikan praktek pengenalan APE dengan media kertas origami dan untuk merangsang semangat dari siswa maka diadakan kompetisi bagi peserta tercepat dan terapi serta memiliki kratifitas terbaik akan mendapatkan reward dalam bentuk alat tulis dan perlengkapan kesekolah. Hal itu dapat secara signifikan memacu semangat siswa untuk berkompetisi sehingga siswa yang tadinya memiliki sifat atau karakter pemalu menjadi ikut aktif dan berani tampil kedepan kelas untuk menjadi peserta demo untuk melipat kertas origami serta memberikan keterangan pada alat peraga lainnya.

Seperti yang disampaikan oleh (Hijriati, 2017) bahwa Alat Permainan Edukatif (APE) dapat menunjang peningkatan kreativitas anak sebabpermainan edukatif merupakan suatu bentuk kegiatan yang dilakukan kepada anak usia dini untuk memperoleh kesenangan atau kepuasan dari cara atau alat pendidikan yang digunakan dalam kegiatan bermain. Ini ditunjukkan dalam Gambar 3. mengenai materi APE.

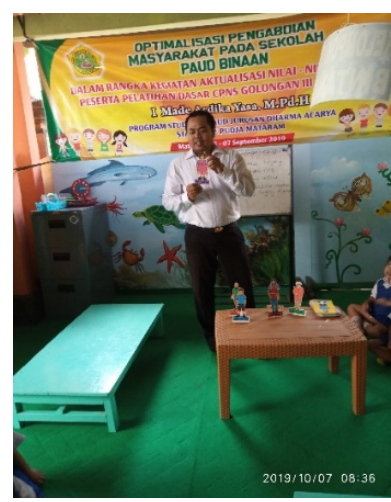

Gambar 3.Penyampaian Materi dan praktik APE ( Sumber: I Made Ardika Yasa)

(Kusumaningtyas et al., 2017) juga menyampaikan bahwa Manfaat APE selain untuk mendukung pertumbuhan dan perkembangananak, juga mendorong aktivitas bermain dan membantu merangsang sifat kepeduliananak terhadap keadaan lingkungan di sekitarnya sehingga dapat memberikan rangsangan terhadap aspek perkembangan anak yang meliputi aspek moral agama, fisik motorik, kognitif, bahasa, sosial emosional dan seni. Dengan demikian dapat kita pahami bahwa Alat Permainan Edukatif ini sangat diperlukan dalam kegiatan belajar mengajar guru di sekolah PAUD oleh karena itu hal ini secara tidak langsung menjadi tangtangan bagi guru paut untuk tetap meningkatkan kreatifitas dan inovasi dalam kegiatan belajar mengajar di PAUD yang mereka kelola agar proses pembelajaran dapat berjalan dengan efektif,efisien sehingga daya serap peserta didik atas materi yang disampaikan dapat diterima secara maksimal. Alat permainan Edukatif ini tidaklah terlalu sulit untuk di buat ataupun membutuhkan biaya yang besar sebab alat permainan edukatif ini dapat dibuat dengan 
menggunakan bahan yang sudah tidak terpakai atau barang bekas seperti bekas botol kemasan minuman, kardus/box bekas, ranting pohon maupun bahan bekas lain yang ada dan dapat diperoleh secara gratis dilingkungan sekitar seperti pada Gambar 4.

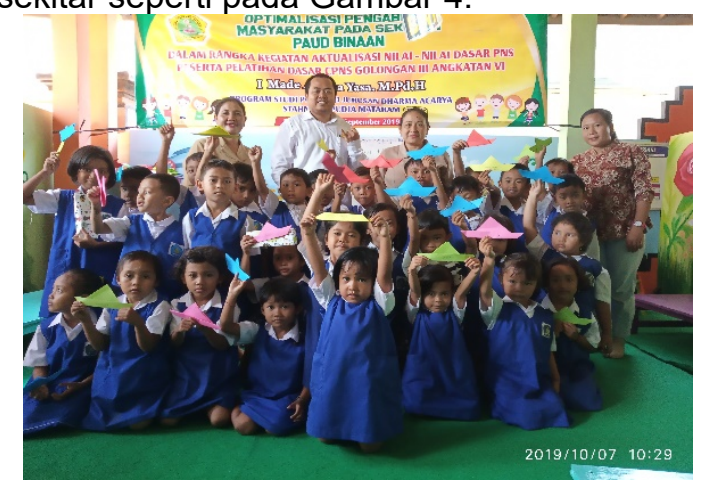

Gambar 4. Hasil praktik APE ( Sumber: I Made Ardika Yasa)

Penyampaian materi nilai-nilai dasar ajaran agama Hindu dan pemberian bantuan fasilitas belajar

Pada sesi ini pelaksana kegiatan pengabdian masyarakat memberikan materi terkait panca sradhaseperti terlihat pada Gambar 5.dan pemahaman tentang manyama brayayang merupakan salah satu pengamalan dari nilai-nilaikerangka dasar ajaran Agama Hindu yang Seharusnya dan sepatutnya ditanamkan pada anak usia dini sebab memiliki nilai edukatif yang sangat penting untuk dapat membentuk karakter anak.Menyama braya perlu untuk dilestarikan dalam berbagai aspek kehidupan manusia baik sosial maupun spiritual sebab itu akan meningkatkan pemahaman tentang konsep tattwam Asi sehingga dapat meningkatkan toleransi, saling menghargai, tenggang rasa, saling mengasihi(Suadnyana, 2018).

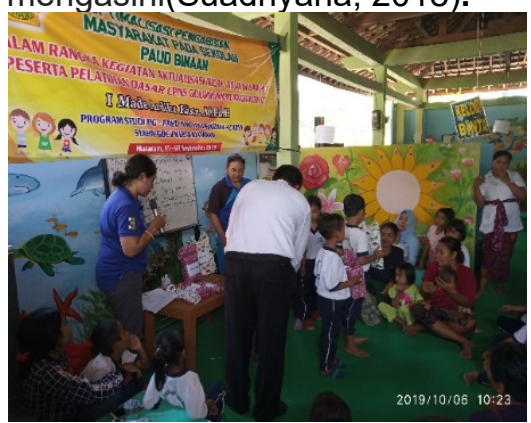

Gambar 5.Pemberian Materi terkait nilai-nilai dasar ajaran agama Hinduuntuk anak usia dini dan bantuan fasilitas belajar( Sumber: I Made Ardika Yasa)

(Suwardani, 2015) didalam jurnalnya menyatakan bahwa Catur Guru sangat berperan dalam menanamkan nilai tradisi atau nilai-nilai kearifan lokal yang dimulai dari lingkungan keluarga, dengan demikian faktor peran keluarga sangat penting membentuk karakter anak yang kuat agar tidak mudah erosi moral dalam menghadapi era milenial ini, sebab pada masa golden age ini adalah masa yang tidak dapat terulang kembali dan merupakan masa yang sangat penting bagi anak dan pada masa inilah daya tangkap dan daya rekam anak sedang tumbuh dan berkembang dengan baik sehingga apa yang dialami pada masa ini akan terpatri dan terekam pada alam bawah sadarnya yang akan selalu diingat hingga dewasa nanti, sebab itulah pada usia dini perlu ditanamkan pemahaman nilai-nilai dasar ajaran agama Hindu yang baik dan benar agar kelak anak tersebut dapat menjaga dan melestarikan budaya serta tradisi maupun kearifan lokal, dan hal itu juga akan dapat membentengi sang anak dari pengaruh negatif modernisasi.

Setelah memberikan materi terkait tentang nilai-nilai dasar ajaran agama Hindu kepada siswa PAUD Dewi Ratih, pelaksanaan kegiatan pengabdian mandiri pada PAUD Binaan prodi PG-PAUD STAH Negeri Gde Pudja Mataram yang pada kesempatan ini berlokasi di PAUD Dewi Ratih memberikan bantuan fasilitas belajar dalam bentuk alat tulis seperti buku tulis, buku pelajaran, pensil, ballpoint, alat peraga, agar secara tidak langsung memberikan edukasi kepada siswa PAUD aplikasi dari nilai-nilai ajaran agama Hindu yang telah disampaikan pada materi tersebut.

\section{Evaluasi Kegiatan Pengabdian Kepada masyarakat di PAUD Binaan}

Evaluasi merupakan salah satu langkah akhir dari proses suatu kegiatan sebab evaluasi merupakan usaha untuk mengidentifikasi, menganalisis,mengukur sejauh mana tingkat keberhasilan suatu kegiatan sesuai dengan aturan,prosedur yang telah ditentukan, hasil dari suatu evaluasi dalam bentuk kesimpulan ataupun nilai yang ditulis pada suatu laporan. Mengevaluasi keberhasilan program pembelajaran tidak cukup hanyaberdasarkan pada indikator penilaian hasil belajar siswa, namun juga perlu menjangkau aspek desain program dan implementasi program pembelajaran(Rifandi, 2013).Berdasarkan hasil interaksi dan komunikasi secara langsung dengan siswa PAUD Dewi Ratih maka kegiatan pengabdian mandiri ini telah berjalan sesuai dengan jadwal dan rencana pelaksanaan yang telah ditentukan.

$$
\text { Proses belajar mengajar }
$$

merupakan suatu kegiatan yang bernilai edukatif, dimana nilai edukatif tersebut tentunya terdapat feedback dari peserta didik atas stimulus dalam bentuk informasi yang telah disampaikan oleh pendidik sehingga tejadi 
interaksi antara pendidik dan peserta didik yang menyebabkan terjalinnya komunikasi timbal balik, agar komunikasi tersebut dapat berjalan dengan lancar maka hindari semaksimal mungkin distorsi yang akan mempengaruhi komunikasi sehingga dapat mengganggu kelancarandalam proses pembelajaran (Susanthi, 2021).

Namun didalam setiap kegiatan pastinya terdapat kendala begitu juga dengan kegiatan pengabdian mandiri ini terdapat beberapa hal yang menjadi kendala diantaranya 1) waktu pelaksanaan yang singkat sehingga proses pelatihan menjadi kurang maksimal, 2) situasi orang tua siswa sebagaian besar memiliki rutinitas tingkat kesibukan yang tinggi sehingga sebagian besar orang tua siswa tidak memiliki kesempatan untuk ikut berpartisipasi dan menemani siswa/peserta didik dalam kegiatan pengabdian secara menyeluruh dari awal sampai selesai walaupun orang tua siswa sangat mendukung kegiatan tersebut dengan memberikan bantuan bahan untuk pelaksanaan kegiatan, 3) pada beberapa sesi kegiatan pengabdian yang dilaksanakan lewat dari jadwal sekolah membuat beberapa anak-anak yang ingin kegiatan cepat selesai dan pulang karena fokus perhatian anak tersebut pada orang tua mereka yang sudah dating menjemput dan berdiri menunggu di halaman luar kelas

Dari beberapa kendala tersebut diatas tentunya ada terdapat keberhasilan, diantaranya 1) Sebagian besarsiswa pada PAUD Dewi Ratih sudah memahami sarana upakara sederhana dan pada saat kegiatan praktik mereka dapat membuat sendiri sarana upakara sederhana tersebut, 2) Siswa PAUD Dewi Ratih sudah memiliki keterampilan dalam membuat Alat Peraga Edukatif terutama melipat kertas origami, 3) Siswa PAUD Dewi Ratih sudah mampu menunjukan keterampilan, bakat dan rasa percaya diri yang dimilikinya dengan bersedia untuk maju menjadi peraga dihadapan orang tua,guru dan teman-temannya dalam Demo membuat sarana Upakara sederhana dan melipat kertas Origami

\section{SIMPULAN DAN SARAN}

Pelaksanaan Pembelajaran di PAUD merupakan tahap awal untuk menciptakan karakter anak sehingga sebagai faktor penentu untuk langkah kejenjang pendidikan lebih tinggi oleh karena itu optimalisasi dalam kegiatan pengabdian masyarakat pada PAUD binaan sangatlah diperlukan dan harusnya terlaksana secara berkesinambungan dan sistematis. Pertisipasi dan antusias orang tua siswa, guru PAUD juga dapat menentukan lancar atau tidaknya suatu proses pengabdian kepada masyarakat, yang dimana pengabdian ini merupakan sebagai bentuk implementasi keilmuan pada PAUD Binaan. Secara umum dapat digambarkan bahwa kegiatan pengabdian masyarakat pada PAUD Binaan sudah berjalan dengan baik, anak-anak sudah mampu mengikuti proses pembelajaran secara antusias dan nyaman mengikuti proses pembelajaran di PAUD dengan alat praga yang di gunakan dalam proses pembelajaran.

Namun karena sifat dan karakter bawaan alami anak yang terbentuk dari pola asuh masing-masing orang tua berbeda sehingga butuh proses adaptasi untuk memahami masing-masing karakter anak sehingga bisa menentukan strategi serta trik agar anak dapat fokus,senang dan antusias secara menyeluruh dalam mengikuti proses pembelajaran. Kedepan diharapkan pengabdian kepada masyarakat pada PAUD Binaan Ini dapat lebih optimal dan berkesinambungan

\section{UCAPAN TERIMAKASIH}

Kegiatan ini tidak akan berjalan dengan lancar tanpa adanya dukungan dari berbagai pihak, baik dalam bentuk materi ataupun non materi. Karena itu ucapan terima kasih disampaikan kepada Manajemen khususnya Kepala Sekolah PAUD Dewi Ratih yang telah memberikan izin melaksanakan kegiatan Pengabdian Kepada Masyarakat pada PAUD yang dikelola dan menerima pelaksana pengabdian dengan baik serta menunjang kegiatan sehingga mendukung kelancaran proses pengabdian. Terima kasih pula disampaikan kepada Orang Tua Siswa yang secara antusias ikut membantu dan mendukung serta menunjang seluruh proses kegiatan pengabdian yang direncanakan sehingga berjalan dengan lancar.

\section{DAFTAR RUJUKAN}

Arta wiguna, I. bagus alit. (2020). Efektivitas Penerapan Metode Hypnoteaching Dalam Meningkatkan Aktivitas Belajar Siswa. PEMBELAJAR: Jurnal IImu Pendidikan, Keguruan, Dan Pembelajaran.

https://doi.org/10.26858/pembelajar.v4i 2.13006

Gunada, I. W. A., \& Yoga Pramana, I. B. K. (2021). Desain Pelatihan Menggambar Ornamen Bali Sebagai Implementasi Nilai Pendidikan Agama Hindu. Jurdimas (Jurnal Pengabdian Kepada Masyarakat) Royal, 4(1), 77-84. https://doi.org/10.33330/jurdimas.v4i1. 909

Hadisi, L. (2015). PENDIDIKAN KARAKTER PADA ANAK USIA DINI La Hadisi. 
Jurnal Al-Ta'did, 8(2), 50-69.

Hariana, K. (2017). Banten Canang Sari sebagai Identitas Budaya Bali dalam Pewarisan Pendidikan Estetika dan Ecoart di Sulawesi Tengah. Seminar Nasional Seni Dan Desain 2017, 58-68.

Hijriati. (2017). Peranan Dan Manfaat Ape Untuk Mendukung Kreativitas Anak Usia Dini. Bunayya : Jurnal Pendidikan Anak, III(2), 59-69. https://jurnal.arraniry.ac.id/index.php/bunayya/article/v iew/1699

Jayanti, N. K. D. A., Novianti, K. D. P., \& Sumalya, I. W. (2017). Implementasi Metode Support Vector Machine Pada Sistem Pengenalan Jejaitan. Seminar Nasional Teknologi Informasi Dan Multimedia, 163-168.

Kaltsum, H. U. (2017). Pemanfaatan Alat Peraga Edukatif Sebagai Media Pembelajaran Bahasa Inggris Sekolah Dasar. Urecol, 19-24.

Khaironi, M. (2017). Pendidikan Karakter Anak Usia Dini. Jurnal Golden Age. https://doi.org/10.29408/goldenage.v1i 02.546

Kunandar. (2008). Langkah Mudah Penelitian Tindakan Kelas sebagai Pengembangan Profesi Guru. Rajawali Press.

Kusumaningtyas, N., Setyoadi, Y., Studi, P., Anak, P., Dini, U., Pendidikan, F. I., Studi, P., Mesin, T., \& Teknik, F. (2017). Rancang Bangun Alat Permainan Edukatif Jenis Gelinding Kelereng. 19(1), 29-35.

Mursid. (2015). Belajar dan Pembelajaran PAUD. PT Remaja Rosdakarya.

Raka Joni, Kardiawarman, \& Hadisubroto, (1998). Penelitian Tindakan Kelas. Bagian Pertama: Konsep Dasar. Jakarta: PGSM, Ditjen DIKTI.

Rifandi, A. (2013). Mutu Pembelajaran Dan Kompetensi Lulusan Diploma lii Politeknik. Jurnal Cakrawala Pendidikan, 5(1), 1-16. https://doi.org/10.21831/cp.v5i1.1266

Studi, P., Informatika, T., \& Indonesia, S. S. (2020). Media Informasi Tentang Makna Kwangen Dalam Persembahyangan Berbasis Animasi 2D. 208-217.

Suadnyana, I. B. P. E. (2018). Kajian Nilai Pendidikan Agama Hindu Dalam Konsep Manyama Braya. Jurnal PASUPATI, $\quad 5(1), \quad 48$. https://doi.org/10.37428/pspt.v5i1.128
Susanthi, I. G. A. A. D. (2021). KENDALA DALAM BELAJAR BAHASA INGGRIS DAN CARA MENGATASINYA. Linguistic Community Service Journal.

Suwardani, N. (2015). Pewarisan Nilai-nilai Kearifan Lokal untuk Memproteksi Masyarakat Bali dari Dampak Negatif Globalisasi. Jurnal Kajian Bali (Journal of Bali Studies), 5(2), 247-264.

Wardhani, I G.A.K. dan Wihardit, K., 2007. Penelitian Tindakan Kelas. Jakarta: Penerbit Universitas Terbuka. 